\title{
Gravimetric and seismic stratigraphy studies applied to Barra Fault System, limit region between Recôncavo and Camamu basins, Bahia, Brazil.
}

\author{
Rigaud, R.A. ${ }^{*}$, UFBA; Vilas-Boas, D.B.R., GETA-UFBA; Batista, J.C., UFBA.
}

Copyright 2019, SBGf - Sociedade Brasileira de Geofísica

This paper was prepared for presentation during the 16th International Congress of the Brazilian Geophysical Society held in Rio de Janeiro, Brazil, 19-22 August 2019.

Contents of this paper were reviewed by the Technical Committee of the 16th International Congress of the Brazilian Geophysical Society and do not necessarily represent any position of the SBGt, its officers or members. Electronic reproduction or represent any position of the SBGf, its officers or members. Electronic reproduction or
storage of any part of this paper for commercial purposes without the written consent of the Brazilian Geophysical Society is prohibited.

\section{Abstract}

Gravity data were measured along the extension of the Itaparica Island. In this region, the limit between Recôncavo and Camamu basins, characterized by the Barra Fault System, is located. These data correspond to previously corrected Bouguer anomaly values and they were processed in order to separate the residual component of the anomaly from its regional component. Gravity maps were created and through its analysis the regional gravity variations of subsurface rocks could be identified. A horizontal gradient filter was applied to the data, allowing the identification of the main and secondary components of the Barra Fault System and of transform faults related to the continental separation process that originated the Eocretaceous Brazilian rift basins. Bidimensional gravity models were created using geological and geophysical data obtained from well logs and from previously interpreted seismic sessions. Gravity interpretation provided an improvement to previous assumptions regarding the basement's depth values. This joint interpretation scheme permitted a further investigation of structural features of the aforementioned basins and complemented the seismic interpretations in regions characterized by low seismic resolution.

\section{Introduction}

The Recôncavo and Camamu basins are inserted in the tectonic context of the Salvador Triple Junction and their origins are related to the fragmentation process that divided the supercontinent Gondwana (Milhomem, 2003). The aborted rift system Recôncavo-Tucano-Jatobá was formed as a consequence of this process, which also developed high-angle normal faults. Amongst these features, the Barra Fault System stands out as it corresponds to the limit between the aforementioned basins.

This region has been investigated using seismic reflection methods in the past, such as in Vilas-Boas et al. (2018), whose work, based on the fundaments of sequence stratigraphy applied to rift basins (model from Holz et al., 2017), resulted on interpreted seismic sessions. They depicted the spatial distribution of main deposit sequences and tectonic system tracts. However, the seismic signal is usually weak along fault planes, with significant energy scattering. Therefore, gravity data were obtained along Itaparica Island, located precisely on the limit between the two basins.

Gravity methods are historically used by the petroleum industry in the study of sedimentary basins to determine basement depths (Telford, 1976). Thus, in this paper, bidimensional gravity models were created in the same location as two of the previously interpreted seismic sessions on this region in order to reproduce the geological features' geometry. The objective of this joint modelling is to complement seismic interpretations in the zones with low seismic signal. The errors associated with the models, defined by the comparison between the observed and the calculated gravity anomaly generated by them, were used as parameters to determine with better precision the efficiency of the models in representing the regional geology and the geometry of the basement, complementing the seismic interpretation (Mattos, 2012).

The gravity data was also processed in order to investigate the regional gravity variations and the Barra Fault System influence on the development of the basin and its sedimentary fill.

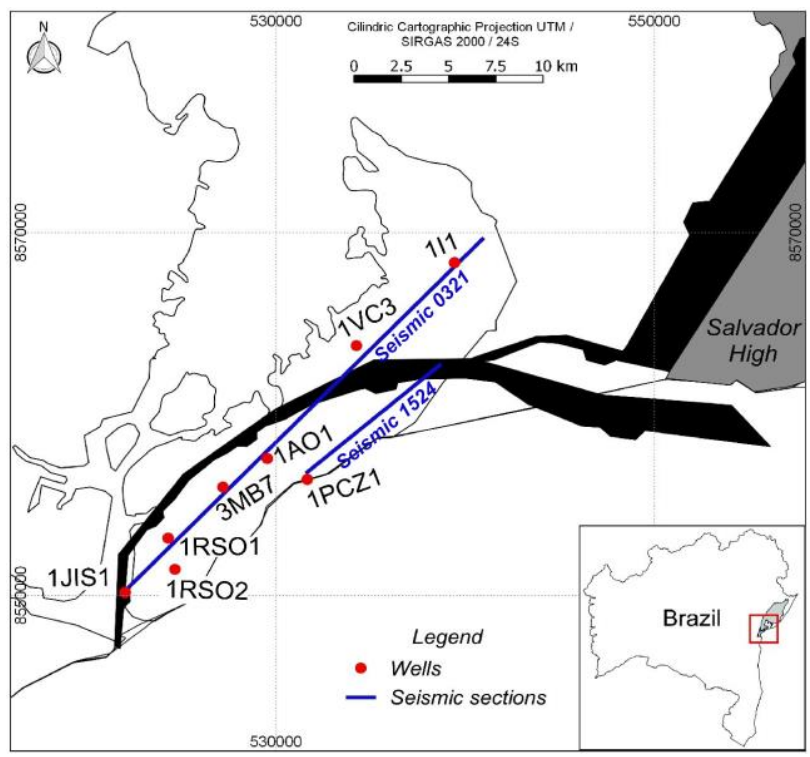

Figure 1 - Location of Itaparica Island and the main segment of Barra Fault System, along with the wells and seismic sections used in this study.

\section{Methodology}

The gravity data utilized in this study were made available by ANP (Agência Nacional de Petróleo, Gás Natural e Biocombustíveis) and they were measured as a part of the terrestrial survey DEXBA-DEXES, which was 
performed by Petrobras along the coast of Bahia and Espírito Santo states. The data were processed using the Oasis Montaj software and the gravity models were constructed using its GM-SYS extension.

The processing was done in order to separate the regional component of Bouguer anomaly from its residual component, which is of interest for modelling (Nabighian et al., 2005). Initially, the anomaly's power spectrum was calculated in order to identify the wavelengths that correspond to the shallow sources, which ranges from 0.4 $\mathrm{m}^{-1}$ to approximately $5.0 \mathrm{~m}^{-1}$. Afterwards, the residual anomaly was filtered from the other components using a band-pass filter.

In order to construct models, approximate depths for the main interpreted sedimentary sequences were obtained from seismic sections and wells. Well density profiles were also used to calculate mean density values corresponding to each main stratigraphic sequence and the bedrock. Afterwards, mean density values for each sequence were calculated and used in modelling, which was developed in order to reproduce the approximate geometry of the sedimentary layers observed in seismic sections while adjusting basement geometry accordingly.

\section{Results and Discussion}

The residual Bouguer anomaly, representing the regional variations of gravity along the island, was plotted using a minimum curvature interpolation method, with a square grid composed of $100 \mathrm{~m}$ length cells. It is observed that negative and weak gravity anomalies, usually associated with deep basement's rocks and significant sedimentary fill, are concentrated on the southern region of the Island. Positive and strong anomalies are located the negative anomalies borders, indicating shallower basement's rocks.
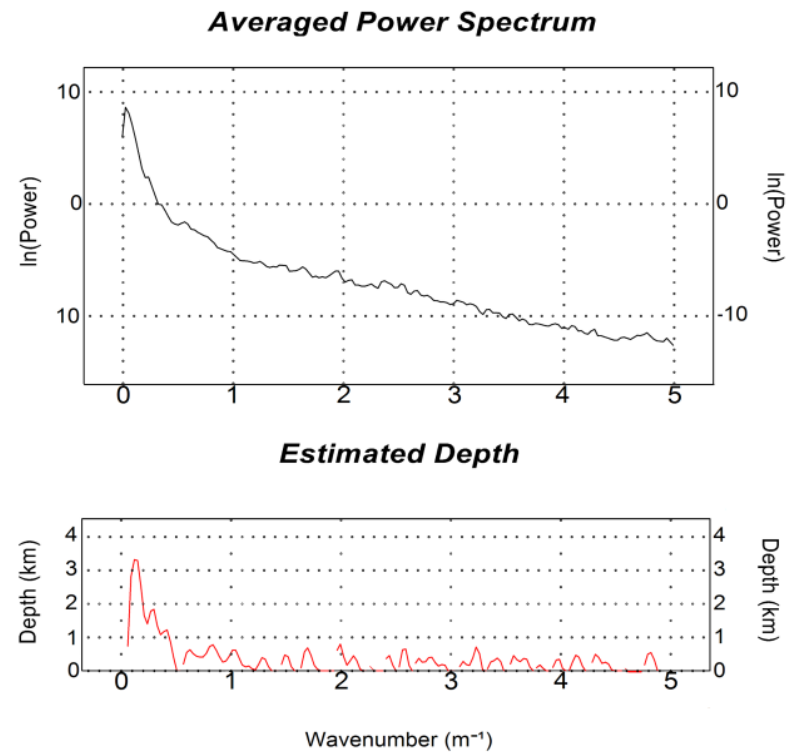

Figure 2 - Bouguer anomaly power spectrum and estimated depths of its sources.

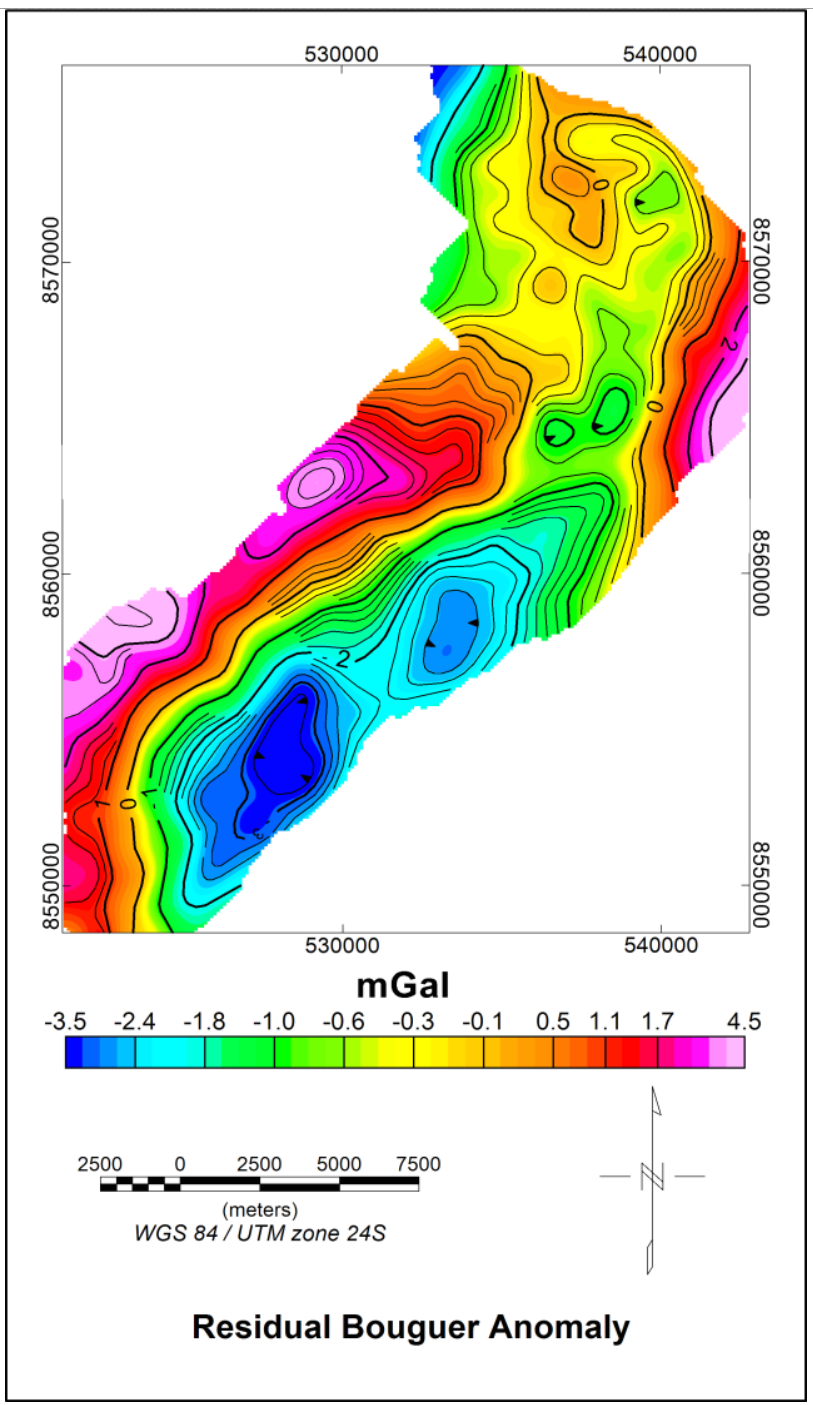

Figure 3-Map of the residual Bouguer anomaly on the Itaparica Island. Two depocenters can be observed in blue, localized in the vicinity of Barra Fault System.

A horizontal gradient filter was applied to the residual gravity anomaly in order to highlight abrupt changes in gravity, such as observed on faults and lineaments (Bello, 2014). The resulting map is exhibited on Figure 3, where four main groups of lineaments, characterized by regions with high gradient values limiting regions with smaller values, could be identified:

- Group L1, characterized by lineaments with NESW orientation and observed on the southwestern region of the Island. High anomaly values are associated with shallower rocks, therefore, these lineaments where interpreted as normal faults that constitute the Barra Fault System;

- Group L2, composed of lineaments with SWWNEE orientation and located on the central region of the Island. They were also interpreted as normal faults of the Barra Fault System;

- Group L3, NW-SE oriented lineaments located on the northern limit of the Island and whose origin was supposed to be related to normal 
faults originated during the evolution of the rift of the Recôncavo basin;

- Group L4, characterized by lineaments with NWSE orientation, in an approximately perpendicular direction to the ones from the Group L1. These lineaments were interpreted as transform faults developed during the formation process of the Camamu basin, being characteristic features of the development of rift basins (Figure 4).

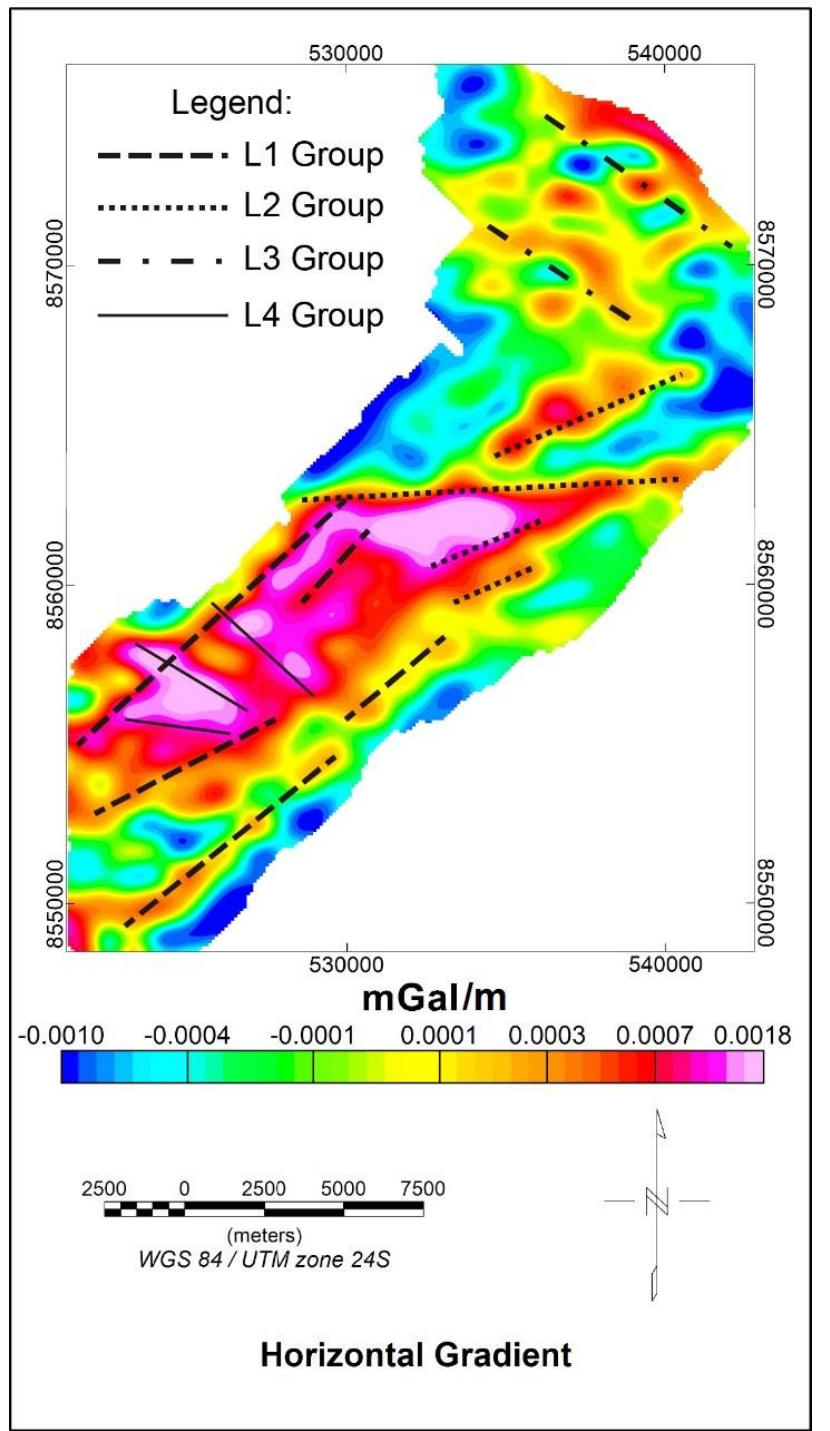

Figure 4- Horizontal gradient of the Bouguer anomaly and the identified groups of lineaments. These are oriented mainly in SW-NE direction (same as Barra Fault System), and a secondarily direction NW-SE.

Analyzing both maps, of interpreted lineaments and observed variations of the Bouguer anomaly, it was observed that the largest lineaments of the groups L1 and L2 separates the domains with positive and high gravity values, located on the northern regions of the Island, from the ones with negative gravity values. Therefore, it was concluded that these lineaments, which represent the main components of the Barra Fault System, correspond to normal faults that caused the ascension of basement's blocks on the north of the Island and the descent of the rocks on the southern region. This shows the structural influence of these structures on the development of the basins and on its sedimentary fill.

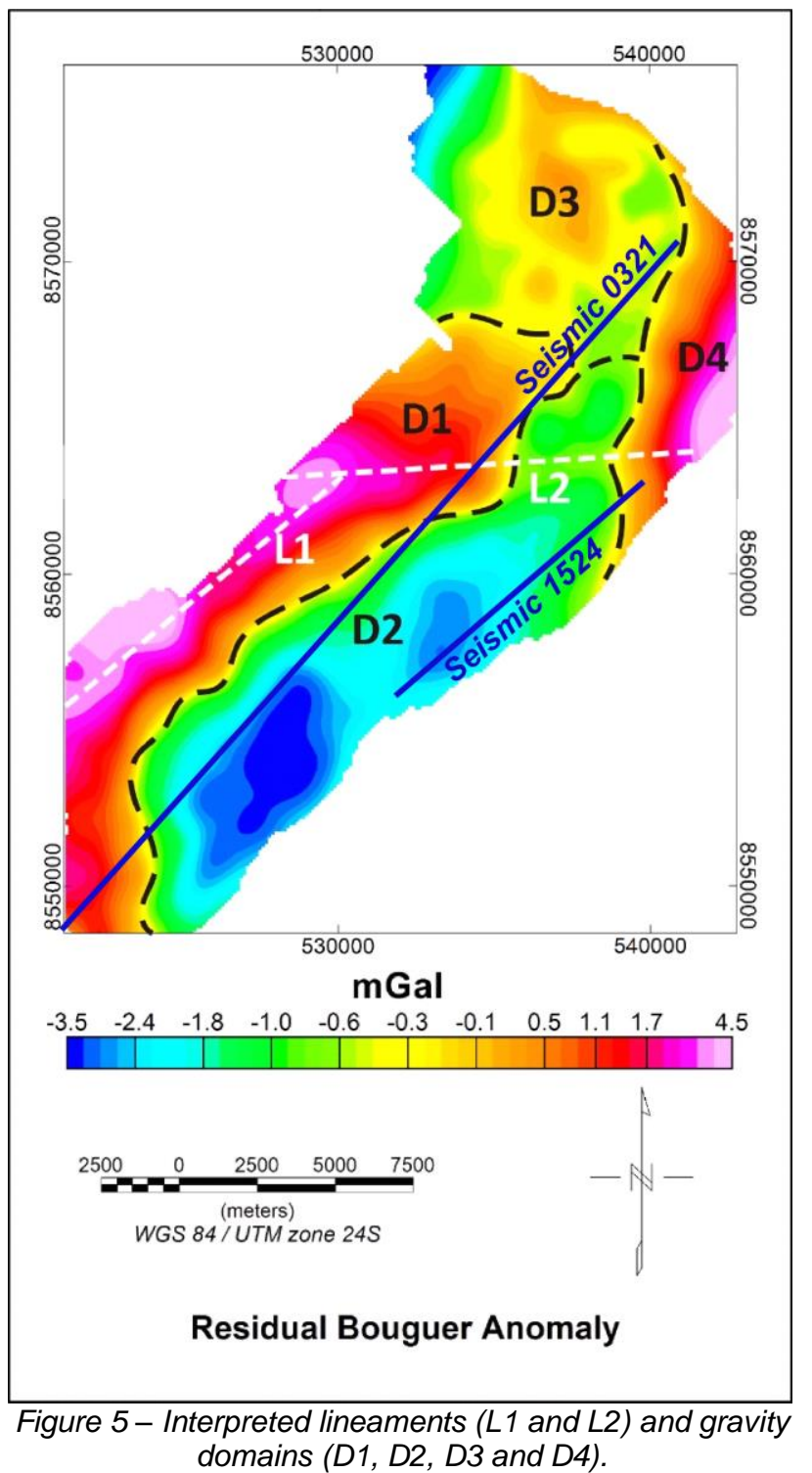

Four main gravity domains could be interpreted from this map. At first, the Domain D1, with high gravity values, consequence of the strong attraction from the rocks that were ascended by Barra Fault; Domain D2, which contains the negative and lowest observed anomalies on the Island, corresponding to the sedimentary fill from the northern limit of the Camamu Basin; and the domains D3 and D4, characterized by high and positive gravity values which are a consequence of the attraction from the rocks of the Salvador High.

The density values used on the construction of the models are exhibited on Table 1 and the first model, reproducing the 1524 seismic line, is exhibited on Figure 6 . This line is located on the domain D3, therefore, it is characterized by negative gravity values and significant 
sedimentary deposition. The interpreted geometry of the sedimentary layers on the seismic section are consistent with the gravity model. From approximately 2.0 to $2.8 \mathrm{~km}$, it is observed a normal fault, which caused the ascension of the basement's rocks until $3.4 \mathrm{~km}$. The deposited sedimentary layer of the Rift 2 sequence is significant, reaching a thickness of $1.2 \mathrm{~km}$.

\begin{tabular}{|c|c|c|c|c|c|c|}
\hline Borehole & $\begin{array}{c}\text { Pre } \\
\text { Rift + } \\
\text { Sag }\end{array}$ & $\begin{array}{c}\text { Rift } \\
\mathbf{1}\end{array}$ & $\begin{array}{c}\text { Rift } \\
\mathbf{2}\end{array}$ & $\begin{array}{c}\text { Rift } \\
\mathbf{3}\end{array}$ & $\begin{array}{c}\text { Rift } \\
\mathbf{4}\end{array}$ & Basement \\
\hline 1PCZ1 & 2.45 & 2.53 & 2.30 & 2,35 & - & - \\
\hline 1RSO1 & & 2.48 & - & - & 2.23 & - \\
\hline 1RSO2 & - & - & 2.39 & - & - & - \\
\hline 1VC3 & 2.39 & 2.41 & & 2.26 & - & 2.80 \\
\hline 3MB7 & 2.50 & 2.47 & 2.43 & 2.37 & 2.36 & - \\
\hline 1I1 & - & - & - & - & - & - \\
\hline $\begin{array}{c}\text { Mean } \\
\text { Density } \\
\left(\mathbf{g} / \mathbf{c m}^{3}\right)\end{array}$ & $\mathbf{2 . 4 5}$ & $\mathbf{2 . 4 7}$ & $\mathbf{2 . 3 7}$ & $\mathbf{2 . 3 3}$ & $\mathbf{2 . 3 0}$ & $\mathbf{2 . 8 0}$ \\
\hline
\end{tabular}

Table 1 - Density value readings obtained from available boreholes and calculated mean density values for the main sedimentary sequences.

The region located between 3.0 and $8,0 \mathrm{~km}$ of extension, limited by the Barra Fault on the right side of the model, exhibits the descent of the basement's rocks due to the effects of the faults, which generates the most expressive sedimentary deposit on the region. These features highlight the structural influence of the normal faults on the formation of the basin.

Such influence can also be seen on the second model, exhibited on Figure 7, defined for the seismic line 0321. This line crosses the Barra Fault System on two regions: approximately at $2.0 \mathrm{~km}$ of distance and at 15 to $16 \mathrm{~km}$. On its first segment, the fault exhibits an inclination of almost $90^{\circ}$ and provokes the descent of the basement and all sedimentary sequences. Minor faults occur along this central region, which cause heterogeneities on the basement surface that do not extend to overlaid layers. The basement's geometry along this region was significantly improved by the use of gravity modelling.

At $15 \mathrm{~km}$, a major component of Barra Fault System causes the uplift of the basement, with a slip of $1 \mathrm{~km}$, and the folding of overlaid sedimentary layers. Due to shallower basement rocks, this region presents the strongest positive gravity anomalies on this model.

\section{Conclusions}

The residual Bouguer anomaly and horizontal gradient maps enabled the investigation of regional gravity variations of along Itaparica Island and its relations with significant geological features, such as the Barra Fault System. The interpretations were in concordance with the regional geology, therefore, it can be concluded that the regional-residual separation method was effective.

The gravity modeling aided the seismic interpretations to identify differences displacements of the Barra Fault System, the basement depth, and also the sequences thickness.

The low errors associated with the gravity models attest to the efficiency of this methodology as a tool to complement seismic interpretations, particularly for oil industry interpretations. Moreover, they also validate the gravity modelling and data interpretation regarding the Barra Fault System.

\section{Acknowledgements}

The authors thanks CPGG-UFBA for infrastructure, VilasBoas thanks for FAPESB and CAPES for postgraduate scholarships and Rigaud thanks ANP for graduate scholarships.

\section{References}

Bello, A.M. (2014) Avaliações comparativas de filtros espaciais para mapeamento de contatos geológicos com contrastes de densidades e susceptibilidade magnéticas, Rel. Téc., Universidade Federal Fluminense, Niterói, Rio de Janeiro.

Holz, M., Vilas-Boas, D. B., Troccoli, E. B., Santana, V. C., \& Vidigal-Souza, P. A. (2017). Conceptual Models for Sequence Stratigraphy of Continental Rift Successions. In Stratigraphy \& Timescales, Vol. 2, pp. 119-186

Mattos, A.S.S. (2012) Aplicação de técnicas de modelagem direta e inversa para a caracterização gravimétrica da Bacia de Santos, Dissert. de Mestrado, Universidade de São Paulo, São Paulo, São Paulo.

Milhomem, P.S.; De Maman, E.J.; Oliveira, F.M. e SouzaLima, W. (2003) Bacias sedimentares brasileiras, Fundação Paleontológica Phoenix, 51:145-154.

Nabighian, M.N.; Grauch, V.J.S.; Hansen, R.O.; Fehr, T.R.; Peirce, J.W.,P.J. D. e Ruder, M.E. (2005) The historical development of the magnetic method in exploration, Geophysics, 70:33-61.

Rigaud, R. A. (2017) Modelagem bidimensional da porção norte da Bacia de Camamu utilizando dados gravimétricos e magnetotelúricos. Trabalho de Graduação, Universidade Federal da Bahia, Salvador, Brasil.

Telford, W.M.; Geldart, L.P.; Sheriff, R.E. e Keys, D.A. (1976) Applied Geophysics, Cambridge University Press, Cambridge.

Vilas-Boas, D.B.R., Souza, P.A.V.D., Holz, M. (2018) Correlação sismoestratigráfica entre as Bacias do Recôncavo e de Camamu, São Paulo, UNESP, Geociências, v. 37, n. 3, p. 467-481. 


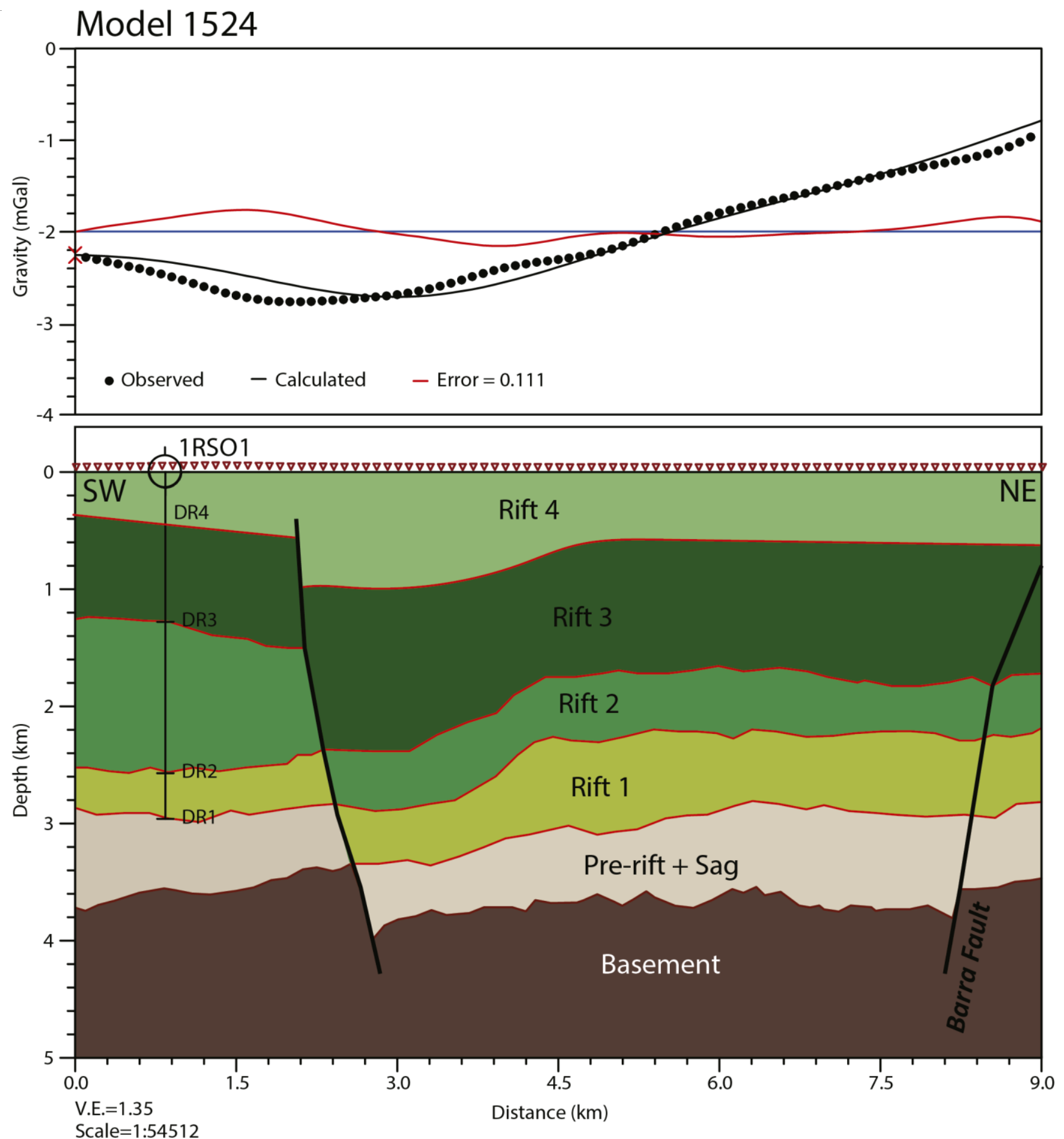

Figure 6 - Gravity model defined for the seismic line 1524. Note the negative gravity anomaly above the main displacement of the Barra Fault, and the thickness of the sequences Rift 3 and Rift 4 (with relative less density). 

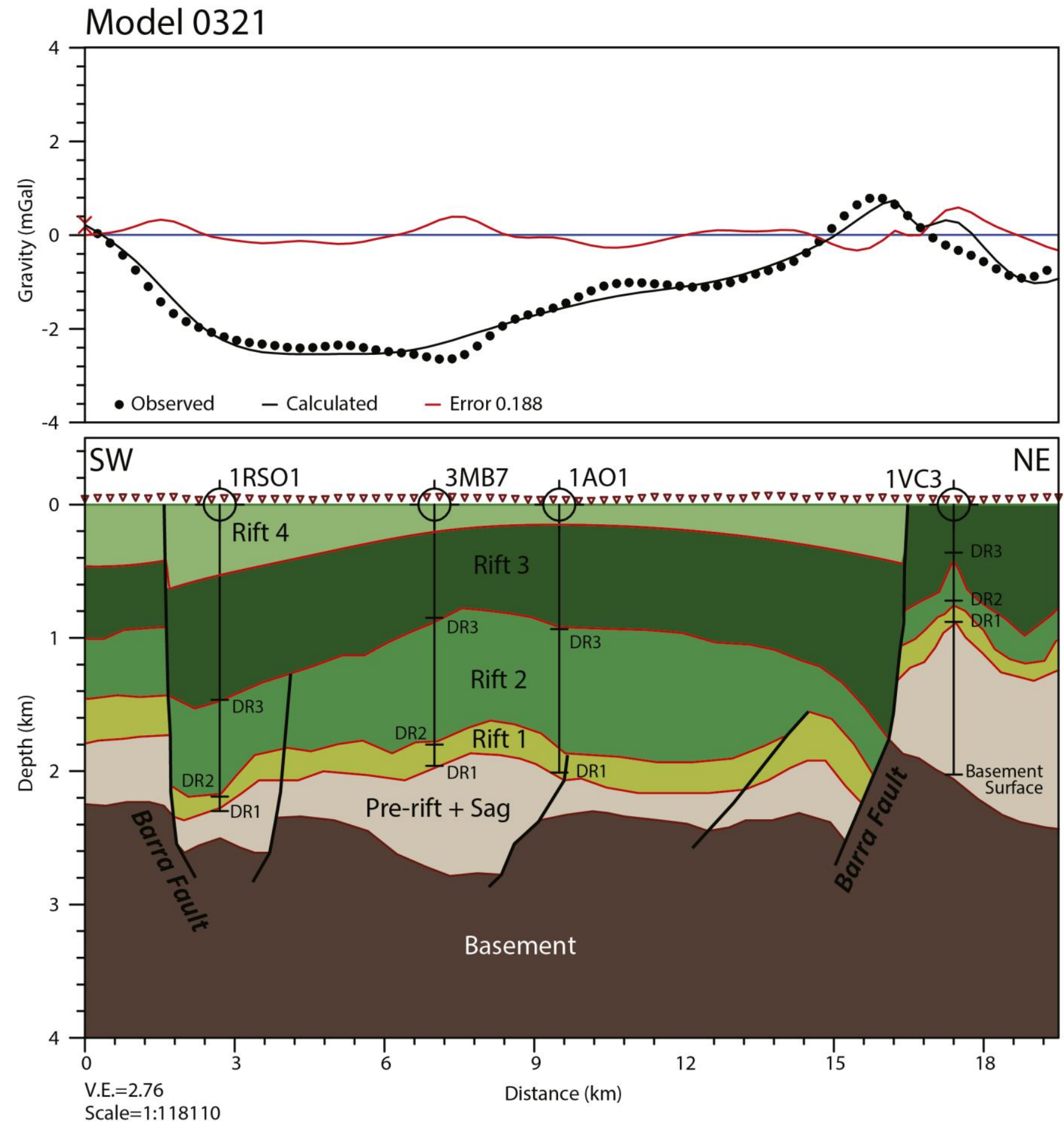

Figure 7 - Gravity model defined for the seismic line 0321 . Note the negative gravity anomaly along the regions of more thickness of the last rift sequences. 